\title{
Severe gynaecomastia associated with highly active antiretroviral therapy
}

\author{
Faith C. Muchemwa ${ }^{1,2}$, Clarice T. Madziyire ${ }^{2}$ \\ 1. Department of Surgery, College of Health Sciences, University of Zimbabwe, Harare, Zimbabwe \\ 2. Department of Immunology, College of Health Sciences, University of Zimbabwe, Harare, Zimbabwe \\ Correspondence: Dr Faith C. Muchemwa (fcmuchemwa@yahoo.co.uk)
}

(C) 2018 F.C. Muchemwa \& C.T. Madziyire. This open access article is licensed under a Creative Commons Attribution 4.0 International License (http://creativecommons.org/licenses/by/4.0/) which permits unrestricted use, distribution, and reproduction in any medium, provided you give appropriate credit to the original author(s) and the source, provide a link to the Creative Commons license, and indicate if changes were made.

East Cent Afr J Surg. 2018 Aug;23(2):80-82 https://dx.doi.org/10.4314/ecajs.v23i2.6

\begin{abstract}
The association between gynaecomastia and HIV infection was first reported in 1987; however, there were no subsequent published reports of gynaecomastia linked to HIV infection until highly active antiretroviral therapy (HAART) was introduced. Although HAART significantly improves the prognosis of HIV infection, its extensive use has resulted in multiple adverse effects, including benign breast enlargement. We present a rare case of severe gynaecomastia in a male patient with vertically transmitted HIV on HAART. He was surgically treated with mastectomy with no nipple-areolar complex reconstruction. The pathology report confirmed the benign nature of the breast tissue. Surgical intervention resulted in an improvement of daily activities and enhanced psychosocial wellbeing.

Benign bilateral breast enlargement of this magnitude in a male patient has never been reported.
\end{abstract}

Keywords: gynaecomastia, HIV, highly active antiretroviral therapy, efavirenz

\section{Introduction}

Gynaecomastia is a benign enlargement of male breast tissue caused by proliferation of the glandular component. Gynaecomastia may be caused by an imbalance between increased oestrogen activity and decreased androgen activity at the breast tissue level. ${ }^{1}$ The association between gynaecomastia and HIV infection was established in 1987, when Couderc and Clauvel reported the onset of transient gynaecomastia in $2 \mathrm{HIV}$-infected patients. ${ }^{2}$ There were no subsequent published reports of gynaecomastia linked to HIV until the introduction of highly active antiretroviral therapy (HAART).

HAART changed the face of the HIV epidemic, resulting in a radical change in the prognosis and management of the disease. However, with the extensive global use of HAART, multiple adverse effects have been described, including breast enlargement in HIV-infected men, most often in association with protease inhibitor-based regimens. ${ }^{3}$ Reports linking gynaecomastia to either nucleoside analogues or non-nucleosides have equally appeared in literature. ${ }^{4}$ Piroth et al. reported an overall incidence of $0.8 / 100$ patient-years, with a prevalence of $2.8 \%$ in those treated for more than 2 years. ${ }^{5}$ Another study reported an incidence of gynaecomastia of $2.3 \%$, with the majority of cases resolving without treatment. ${ }^{6}$ Although prevalence of HIV-associated gynaecomastia is low, the resultant psychosocial impact, cosmetic problems, and physical challenges are causes for concern and little research has been done in this area.

Various studies have implicated antituberculosis chemotherapy, specifically isoniazid, as a cause of gynaecomastia; however, the prevalence and incidence are not known. Case reports published agree that cessation of these drugs result in resolution of gynaecomastia; therefore, medical or surgical intervention is generally not required.

\section{Case presentation}

\section{History and examination}

A 27-year-old male patient with vertically transmitted HIV presented with a 3-year history of bilateral breast enlargement and a 2 year history of difficulty mobilizing. His diagnosis of HIV had been confirmed at the age of eleven, at which time he was commenced on triple antiretroviral therapy (stavudine, lamivudine, and nevaripine). At the age of 23, his regimen was switched to tenofovir, lamivudine, and efavirenz. His gynaecomastia became noticeable 3 months after the change in HAART and progressively increased in severity over 3 years. The patient only managed to seek medical assistance at a tertiary hospital when well-wishers offered their help. In his past medical history, he was diagnosed with and treated for tuberculosis at the age of 22 and again for a 
recurrence at age 26; he was also taking sulphamethoxazole/ trimethoprim (cotrimoxazole) as standard prophylaxis.

On examination, he was found to be cachectic, with bilateral and asymmetrical enlargement of his breasts, with the right breast significantly larger than the left. There was excoriation of skin around the breast, along with hypopig-

\begin{tabular}{|c|c|c|}
\hline Variable & $\begin{array}{c}\text { Patient } \\
\text { value }\end{array}$ & $\begin{array}{c}\text { Lab Reference } \\
\text { range }\end{array}$ \\
\hline Luteinising hormone & 13.9 & $1.86-8.6$ \\
\hline $\begin{array}{l}\text { Follicle stimulating } \\
\text { hormone }\end{array}$ & 2.85 & $1.3-19.3$ \\
\hline S17b Estradiol & 125 & $<191 \mathrm{pmol} / \mathrm{l}$ \\
\hline Prolactin & 14.4 & $2.1-15 \mathrm{ng} / \mathrm{ml}$ \\
\hline Total Testosterone & 28.4 & $>12 \mathrm{nmol} / \mathrm{l}$ \\
\hline Free Testosterone & 164 & 180-730 pmol// \\
\hline $\begin{array}{l}\text { Sex hormone } \\
\text { binding globulin }\end{array}$ & 174.4 & $11.1-78.4 \mathrm{nmol} / \mathrm{l}$ \\
\hline AST & 26 & $14-59 \mathrm{U} / \mathrm{L}$ \\
\hline ALP & 114 & 44-147 IU/L \\
\hline ALT & 12 & $7-56 \mathrm{U} / \mathrm{L}$ \\
\hline TP & 73 & $60-83 \mathrm{~g} / \mathrm{L}$ \\
\hline Albumin & 38 & $35-55 \mathrm{~g} / \mathrm{L}$ \\
\hline GGT & 26 & $0-45 \mathrm{U} / \mathrm{L}$ \\
\hline Total bilirubin & 5 & $2-20 \mu \mathrm{mol} / \mathrm{L}$ \\
\hline TSH & 2.85 & $0.35-\mathrm{IU} / \mathrm{mL}$ \\
\hline CD4 & 479 & \\
\hline Viral load & Undectable & \\
\hline
\end{tabular}

mentation and poor nipple-areolar differentiation resulting from chronic stretching. The breasts were nontender with no obvious lumps, and there were no palpable lymph nodes. He had normal male hair distribution, and the testicular examination was unremarkable. There were no stigmata of liver disease. Psychological examination led to a diagnosis of depression, and the patient was started on clinical psychotherapy preoperatively. Efavirenz, which was suspected to be the cause of his gynaecomastia, was stopped and substituted with nevirapine.

\section{Laboratory and radiologic investigations}

Laboratory tests results are summarized in Table 1 . HIV viral load was undetectable and the CD4+ cell count was normal (497cells/ $\mu \mathrm{l})$. No abnormalities were found on routine blood tests (liver function tests, full blood count, and urea and electrolytes). Free and total testosterone levels were low, and sex hormone binding globulin and luteinizing hormone levels were elevated, indicating hypogonadism. Magnetic resonance imaging of the brain and $\mathrm{x}$-rays of the cervical spine and chest were unremarkable.

\section{Surgical intervention}

The patient was informed of possible surgical options and opted for mastectomy with no nipple-areolar complex reconstruction. Four kilograms of breast tissue was excised from the right breast, and the left breast tissue weighed 3 kg. Clinical photographs are shown in Figure 1. Histological examination revealed benign glandular breast tissue embedded in a fibrous stroma.

\section{Discussion}

Gynaecomastia with severe ptosis of this magnitude has never been reported. The surgical management of gynaecomastia in HIV patients is not well characterized. Many patients present with mild-to-moderate breast enlargement, which can be dealt with by subcutaneous mastectomy. The extent of gynaecomastia with severe ptosis encountered in this case is a rare occurrence.

The aetiopathogenesis of this phenomenon remains unclear. Efavirenz has been associated with gynaecomastia in
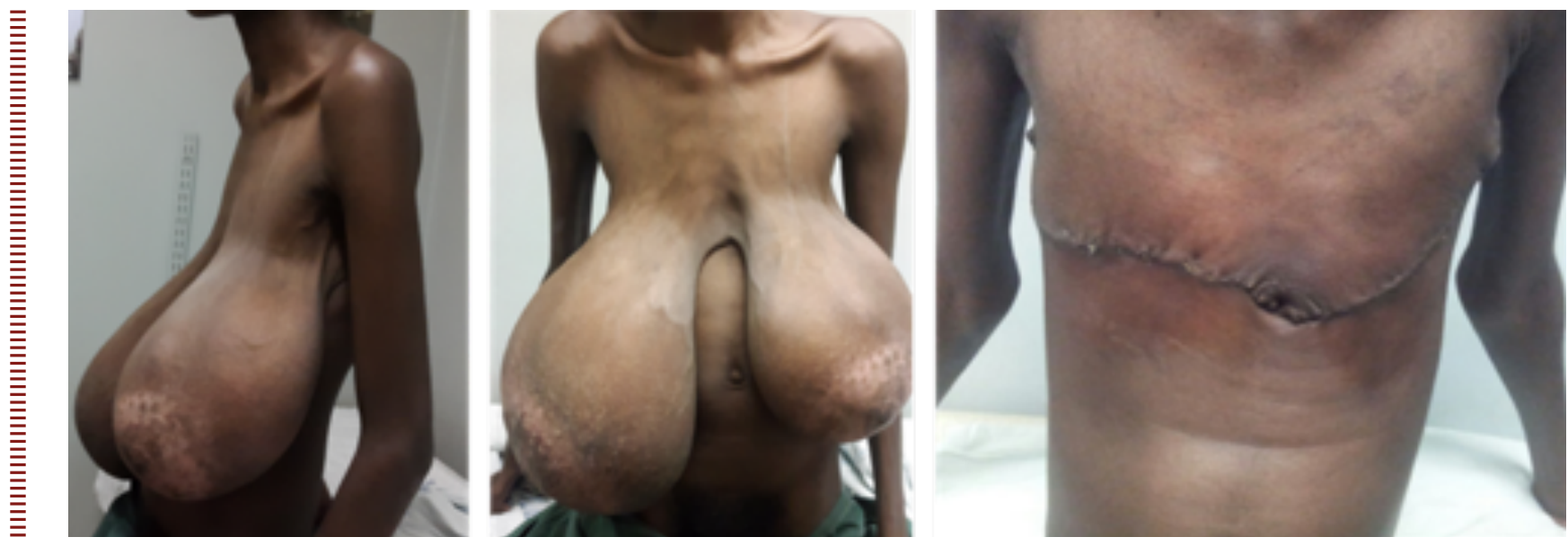

Figure 1. Preoperative and postoperative (far right) photographs 
some reports ${ }^{7,8}$; this has led to noncompliance as a result of fear of side effects or stigmatization. In some instances, patients who present at the onset of gynaecomastia have benefited from discontinuation of some of the antiretroviral drugs; however, spontaneous resolution can occur without stopping treatment. Persistent enlargement of breast tissue in men may result in the replacement of glandular tissue with inactive fibrotic tissue, and surgery is the only suitable modality of management in such cases.

HIV infection may directly or indirectly affect the glandular, mesenchymal, and intramammary lymphoid tissue in seropositive patients. Benign stromal changes include gynaecomastia, adipose tissue deposition as part of the fat maldistribution syndrome, and pseudoangiomatous stromal hyperplasia. ${ }^{9}$

Rohrich et a $1 .{ }^{10}$ proposed a classification of gynaecomastia with four grades of severity: grade I - minimal hypertrophy $(<250 \mathrm{~g})$ without ptosis; grade II - moderate hypertrophy (250-500 g) without ptosis; grade III - severe hypertrophy ( $>500 \mathrm{~g}$ ) with grade I ptosis; grade IV - severe hypertrophy with grade II or grade III ptosis. Using this classification, our report reflects the worst and most severe type of gynaecomastia. There have been reports of breast carcino- ma in patients presenting with gynaecomastia; however, our case had benign breast tissue.

\section{Conclusions}

In this case report, we have described the surgical management of a striking case of HAART-induced severe breast hypertrophy with grade III ptosis (grade IV gynaecomastia) in a 27-year-old male patient. Patient wishes regarding the preferred surgical procedure, patient satisfaction, and the final functional outcome are more gratifying than the resultant cosmetic appearance of the male chest. This patient was pleased with his result and was discharged mobilizing without hindrance.

Although great strides have been made in sub-Saharan Africa to reduce new HIV infections, improve quality of life, and prolong life expectancy among HIV-infected patients, side effects of drugs can lead to extremely distressing symptoms.

\section{Competing interests}

Both authors declare that they have no competing interests related to this work.

\section{References}

1. Johnson RE, Murad MH. Gynecomastia: pathophysiology, evaluation, and management. Mayo Clin Proc. 2009 Nov;84(11):1010-5. doi: 10.1016/S00256196(11)60671-X.

2. Couderc LJ, Clauvel JP. HIV-infectioninduced gynecomastia. Ann Intern Med. 1987 Aug;107(2):257. doi: 10.7326/00034819-107-2-257_1.

3. Jover F, Cuadrado JM, Roig P, Rodríguez M, Andreu L, Merino J. Efavirenz-associated gynecomastia: report of five cases and review of the literature. Breast J. 2004 May-Jun;10(3):244-6. doi: 10.1111/j.1075122X.2004.21392.x.

4. Pantanowitz L, Sen S, Crisi GM, MakariJudson G, Garb J, Skiest D. Spectrum of breast disease encountered in HIVpositive patients at a community teaching hospital. Breast. 2011 Aug;20(4):303-8 doi: 10.1016/j.breast.2010.08.003. Epub 2011 Jun 8.
5. Piroth L, Grappin M, Petit JM, Buisson $M$, Duong $M$, Chavanet $P$. Incidence of gynecomastia in men infected with HIV and treated with highly active antiretroviral therapy. Scand J Infect Dis. 2001;33(7):559-60. doi: 10.1080/00365540110026476.

6. Mira JA, Lozano F, Santos J, Ramayo E, Terrón A, Palacios R, et al. Gynaecomastia in HIV-infected men on highly active antiretroviral therapy: association with efavirenz and didanosine treatment Antivir Ther. 2004 Aug;9(4):511-7.

7. Dawood H. Adolescent HIV treatment issues in South Africa. S Afr Med J. 2015 Nov;105(11):953.
8. Rahim S, Ortiz O, Maslow M, Holzman R. A case-control study of gynecomastia in HIV-1-infected patients receiving HAART. AIDS Read. 2004 Jan;14(1):23-4, 29-32, $35-$ 40.

9. Pantanowitz L, Connolly JL. Pathology of the breast associated with HIV/AIDS. Breast J. 2002 Jul-Aug;8(4):234-43. doi: 10.1046/j.1524-4741.2002.08409.x.

10. Rohrich RJ, Ha RY, Kenkel JM, Adams WP Jr. Classification and management of gynecomastia: defining the role of ultrasound-assisted liposuction. Plast Reconstr Surg. 2003 Feb;111(2):90923; discussion 924-5. doi: 10.1097/01. PRS.0000042146.40379.25. 